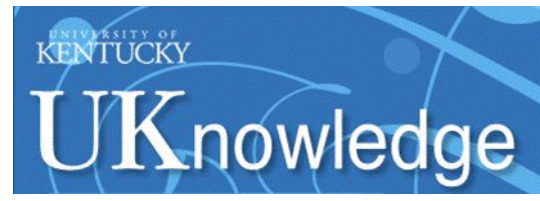

University of Kentucky

UKnowledge

$11-2008$

\title{
Cardiovascular Disease (CVD)
}

Jackie Walters

University of Kentucky

Follow this and additional works at: https://uknowledge.uky.edu/fcs_reports

Part of the Dietetics and Clinical Nutrition Commons, and the Diseases Commons

Right click to open a feedback form in a new tab to let us know how this document benefits you.

\section{Repository Citation}

Walters, Jackie, "Cardiovascular Disease (CVD)" (2008). Family and Consumer Sciences Publications. 62. https://uknowledge.uky.edu/fcs_reports/62

This Report is brought to you for free and open access by the Cooperative Extension Service at UKnowledge. It has been accepted for inclusion in Family and Consumer Sciences Publications by an authorized administrator of UKnowledge. For more information, please contact UKnowledge@lsv.uky.edu. 


\section{Cardiovascular Disease (CVD)}

Cardiovascular disease (CVD) is an illness that affects the heart and/or blood vessels. CVD starts as fatty plaque builds up on the inner wall of the arteries. Over time, this buildup leads to arteriosclerosis, or hardening of the arteries. As arteries become more filled with plaque, the space open for blood flow shrinks. The force of the heart pumping blood through ever smaller blood vessels raises blood pressure. The force stresses the arteries and the heart. Hardening of the arteries allows blood to clot within the arteries. If a blood clot breaks off, it could lodge within an artery. Then blood cannot flow to or from the heart. This is when a heart attack happens. If a blood clot breaks off and lodges in an artery in the brain, it causes a stroke.

CVD is the leading cause of death in every county in Kentucky and every state in the nation. It is the leading cause of death for both men and women. Yet, most of the risk factors for CVD can be prevented.

\section{Risk Factors}

- Physical inactivity

- Poor nutrition

- Tobacco use

- Diabetes

- Obesity

- High blood cholesterol

- High blood pressure

- Family history

- Minority or ethnic heritage
Is your fasting blood sugar

Normal Below $100 \mathrm{mg} / \mathrm{dl}$

Pre-Diabetes Between 100 and $125 \mathrm{mg} / \mathrm{dl}$

Diabetes Higher than $126 \mathrm{mg} / \mathrm{dl}$

\section{Is your blood cholesterol}

$\square$ Excellent Below $200 \mathrm{mg} / \mathrm{dl}$

$\square$ Fair 200 to $240 \mathrm{mg} / \mathrm{dl}$

Poor Above $240 \mathrm{mg} / \mathrm{dl}$

Is your blood pressure lower than 140/90 $\mathrm{mm} \mathrm{Hg}$ ?

$\square$ YES $\square$ NO

\section{List your risk factors:}

1.

2.

3.

4.

5.

6.

7.

8.

9. 


\section{What changes could you make to reduce your risk factors?}

1.

2.

3.

4.

5.

6.

7.

\section{,}

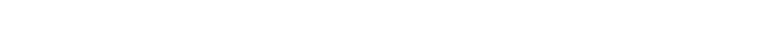

The best way to prevent CVD is to maintain a healthy weight. Eat well and stay active. Follow the U.S. Department of Agriculture (USDA) dietary guidelines. Have regular check-ups. Make sure your blood pressure, blood sugar and blood cholesterol are within healthy ranges. Your health is your wealth!

\section{Sources}

The American Heart Association, www.americanheart.org

The American Diabetes Association, www.diabetes.org/about-diabetes.jsp

\section{WWW.diabetes.org/about-diabetes.jsp}

